\title{
Isolation and Identification of Dibenzothiophene Biodesulfurizing Bacteria
}

\author{
Majid Hussein Al-Jailawi 1, ", Albab Fawaz Al-Faraas², Abdelghani Ibrahem Yahia ${ }^{1}$ \\ ${ }^{1}$ Department of Molecular \& Medical Biotechnology, College of Biotechnology, Al-Nahrain University, Baghdad, Iraq \\ ${ }^{2}$ Department of Biotechnology, College of Science, Al-Nahrain University, Baghdad, Iraq
}

\section{Email address:}

majed_algelawi@hotmail.com (M. H. Al-Jailawi)

\section{To cite this article:}

Majid Hussein Al-Jailawi, Albab Fawaz Al-Faraas, Abdelghani Ibrahem Yahia. Isolation and Identification of Dibenzothiophene Biodesulfurizing Bacteria. American Journal of Bioscience and Bioengineering. Vol. 3, No. 5, 2015, pp. 40-46.

doi: $10.11648 /$ j.bio. 20150305.13

\begin{abstract}
This study aimed to obtain efficient bacteria capable of desulfurizing dibenzothiophene (DBT). For this purpose forty oil contaminated soil samples were collected from different sites in Iraq. It was found that three isolates (M9, M19 and S25) had the ability to desulfurize DBT (cleave C-S bond) and converted it to 2-hydroxybiphenel (2-HBP) or other phenolic end products. This suggests the involvement of the 4S pathway in the desulfurizing of DBT via a specific cleavage of only the C-S bond by these isolates. These isolates were identified as Pseudomonas aeruginosa. The result also showed that $P$. aeruginosa S25 was the most efficient one for removing sulfur from DBT. The GC/MS analysis for DBT after growth of $P$. aeruginosa S25, indicated that $12.89 \%$ of DBT was consumed (consumption of sulfur), and the product (2-HBP) was further converted to 2-MBP (addition of a methyl group) and this could be a novel pathway for consuming DBT.
\end{abstract}

Keywords: Dibenzothiophene, Biodesulfurization, Isolation, P. aeruginosa, GC/MS

\section{Introduction}

Crude oil (Petroleum hydrocarbon) continues to be used as the principle source of energy and hence a large global environmental pollutant, due to the possibility of air, water and soil contamination. Petroleum is a complex mixture of non-aqueous and hydrophobic components. Many of these components are toxic, mutagenic and carcinogenic (Mandal et al., 2012). The increasing sulfur content of crude oil also results in an increase in sulfur content in automotive gasoline diesel fuel, and jet fuel. To meet the needs for producing clean fuels, decreasing the sulfur content of crude oil becomes an urgent task. Studying new desulfurization technology and raising the efficiency of desulfurization processes are the keys to bringing more profits to the oil refining companies (Liu et al., 2007). At present, numerous desulfurization methods have been developed. Among them hydrodesulfurization (HDS) has been widely applied to the field of petroleum fuel production around the world for a long time. HDS has short comings such as lower desulfurization efficiency, strict reaction conditions and so on, which leads to higher manufacturing costs and higher price of the resulting fuel, therefore, the search for new desulfurization technologies which offer higher efficiency and lower manufacturing costs has become a hot research topic in this field (Gao et al., 2009; Ma et al., 2013). However, HDS has several disadvantages, in that it is energy intensive, costly to install and to operate, and does not work well on refractory organosulfur compounds. Research has therefore focused on improving HDS catalysts and processes and also on the development of alternative technologies. Compared with HDS process, the biodesulfurization (BDS) process using microorganisms and/or enzymes could be carried out more safely, under mild conditions (Chen et al., 2009). Removal of inorganic sulfur from fossil fuels is possible by physical, chemical or biological means. Physical and chemical methods are expensive mean (Monticello et al., 2000), while biodesulfurization (BDS) is a process which is requires lower capital cost as it operates at mild conditions of atmospheric temperature and pressure and does not require molecular hydrogen (Alves and Paixão, 2011). It also produces far less carbon dioxide than HDS (Kilbane, 2006). The compound dibenzothiophene (DBT) has received most attention in biodesulfurization studies because it is an accepted model compound representative of thiophenic structures found in coal and petroleum. For this reason, biodesulfurization of crude oil and its fractions has been 
studied extensively (Kilbane 2006; Mohebali and Ball, 2008; $\mathrm{Xu}$ et al., 2009). Fuel desulfurization represented an opportunity for a cost effective solution to acid rain and other health hazard caused by sulfurous emission (Rhee et al., 1998; Mohebali et al., 2007). According to those mentioned above, the aim of the present work was to obtain potential biocatalists (bacterial isolates) for desulfuring of dibenzothiophene (DBT).

\section{Materials and Methods}

\subsection{Isolation of Bacteria}

Oil - contaminated soil samples were collected from forty different sites, with a history of oil pollution, in Iraq. The microbial selection procedures were performed in basal salt media (BSM) ( $\mathrm{pH}$ 7.2) constituted of $\mathrm{K}_{2} \mathrm{HPO}_{4}(4 \mathrm{~g})$; $\mathrm{Na}_{2} \mathrm{HPO}_{4}(4 \mathrm{~g}) ; \mathrm{NH}_{4} \mathrm{Cl}(2 \mathrm{~g}) ; \mathrm{MgCl}_{2} \cdot 6 \mathrm{H}_{2} \mathrm{O}(0.2 \mathrm{~g})$; $\mathrm{CaCl}_{2} .2 \mathrm{H}_{2} \mathrm{O}(0.001 \mathrm{~g})$ and $\mathrm{FeCl}_{3} \cdot 6 \mathrm{H}_{2} \mathrm{O}(0.001 \mathrm{~g})$ per liter of distilled water. One hundred milliliter of BSM were dispensed in the $250 \mathrm{ml}$ Erlenmeyer flasks supplemented with $0.1 \mathrm{mM}$ of DBT as a sole source of sulfur and glycerol $(10 \mathrm{mM})$ as a carbon source, autoclaved at $121^{\circ} \mathrm{C}$ for $15 \mathrm{~min}$. One percent $(\mathrm{w} / \mathrm{v})$ of soil samples was added to the flasks and incubated at $30{ }^{\circ} \mathrm{C}$ with shaking $(150 \mathrm{rpm})$ for four days. Samples $(0.1 \mathrm{ml})$ of appropriate dilutions were spread onto plates of LB agar plates, incubated at $30{ }^{\circ} \mathrm{C}$ for $24 \mathrm{hrs}$. A single colony was picked with a sterile loop to prepare a pure subculture in a fresh LB agar plates by streaking. The purity of the isolated colonies was checked by microscopic examination. Pure isolates were growing in BSM medium containing DBT and glycerol (as mentioned above) to ensure their ability to desulfurize DBT.

\subsection{Preparation of the Bacterial Inoculates}

The bacterial isolates were grown in flasks containing DBTglycerol- BSM media at $35^{\circ} \mathrm{C}$ with shacking $(150 \mathrm{rpm})$ for 18 hrs. Cells were harvested by centrifugation $(10,000 \times \mathrm{g})$, washed twice, and resuspended in BSM media lacking DBT and glycerol. The resulting suspension was used as the bacterial inoculum. The size of the inoculum used in all experiments was $1 \%(\mathrm{v} / \mathrm{v})$.

\subsection{Screening the Biodesulfurization Activity of Bacterial Isolates Using Gibb's Assay}

Gibb's assay was used to determine the presence of DBT biodesulfurizing bacteria that exhibit the $4 \mathrm{~S}$ pathway by the detection of 2-hydroxybiphenyl (2-HBP) which is the end product of the $4 \mathrm{~S}$ pathway. The cell- free culture supernatant was obtained from $50 \mathrm{ml}$ of bacterial cultures, grown at $35^{\circ} \mathrm{C}$ for 4 days, by centrifugation $\left(10,000 \times \mathrm{g}, 10 \mathrm{~min}\right.$, at $\left.4{ }^{\circ} \mathrm{C}\right)$. One $\mathrm{ml}$ of each cell-free supernatant was transferred to clean eppendorf and adjusted to $\mathrm{pH} 8$ by adding $60 \mu \mathrm{l}$ of $1 \mathrm{M}$ $\mathrm{NaHCO}_{3}$ (Konishi et al., 1997) or by adding $3 \mu \mathrm{l}$ of $4 \mathrm{M}$ of $\mathrm{NaOH}$. Detection of the end products of the desulfurization of thiophene compound, was carried out in microtiter plates by adding $3 \mu \mathrm{l}$ of Gibb's reagent (2,
6-Dichloroquinone-4-Chloroimide, $1 \mathrm{mg} / \mathrm{ml}$ in ethanol) to $300 \mu 1$ of cell- free supernatant $(\mathrm{pH} 8)(1: 100)$ and the mixture was kept at room temperature for $30 \mathrm{~min}$. Bacterial cultures capable of desulfurizing thiophene compound, accumulated phenolic compounds in cultural supernatant and gave blue color in the presence of Gibb's reagent (Rambosek, 1994).

\subsection{Identification of Bacterial Isolates}

Morphological, physiological and biochemical tests were performed to identify the isolates as recommended by Holt et al. (1994). The identification was confirmed by the VITEK 2 system.

\subsection{Selection the Efficient Isolate That Capable of Desulfurizing $\mathrm{DBT}$}

The efficient bacterial isolate capable of desulfurizing DBT (as S-source only) was chosen depending on Gibb's assay. The bacterial isolates were grown in BSM supplemented with double concentrations of DBT $(0.1,0.2,0.4,0.8 \mathrm{mM})$ at $35^{\circ} \mathrm{C}$ for 4 days. Then Gibb's assay was performed (as mentioned above) and the developing blue color reading at $610 \mathrm{~nm}$ using UV/VIS- Spectrophotometer.

\subsection{Detection and Verifying the Biodesulfurizing Products by GC/MS Analysis}

\subsubsection{Biodesulfurization of DBT by Resting Bacterial Cells (Al-Hassar, 2010)}

$P$. aeruginosa S25 was grown in $500 \mathrm{ml}$ of BSM containing $0.6 \mathrm{mM}$ DBT (as sole S-source) at $35{ }^{\circ} \mathrm{C}$. The culture with O.D $D_{580}$ of 1.421 - 1.602 were centrifuged $(10,000$ $\mathrm{rpm}, 4{ }^{\circ} \mathrm{C}$ for $15 \mathrm{~min}$ ) to harvest the cell pellets, washed twice with BSM and resuspended in $500 \mathrm{ml}$ DBT-BSM and incubated at $35{ }^{\circ} \mathrm{C}$ for $48 \mathrm{~h}$. The resulting cell pellets were washed once and then suspended in $50 \mathrm{ml}$ of BSM lacking DBT to prepare bacterial cell suspension. Conical flask (250 $\mathrm{ml}$ ) containing $70 \mathrm{ml}$ of BSM supplemented with $0.6 \mathrm{mM}$ DBT was inoculated with $5 \mathrm{ml}$ of cell suspension. These flasks in addition to non inoculated flasks, served as control for biotic losses, were incubated under shaking (150 rpm) at $35{ }^{\circ} \mathrm{C}$ for 3 days. After incubation the cultures were centrifuged to separate bacterial cell, then one ml of culture supernatant was extracted with $3 \mathrm{ml}$ of ethyl acetate, this solvent was evaporated by lyophilizer and the residue was dissolved in $100 \mu$ l ethanol.

\subsubsection{GC/MS Analysis (Smart et al., 2010)}

The selective detection of the sulfur species was traced by using gas chromatography mass- spectrometer (GC/MS). The GC/MS analysis was conducted with capillary ultra 2 columns (25 mm length, $0.32 \mathrm{~mm}$ inner diameter, $0.52 \mu \mathrm{m}$ film thickness, and $3.2 \mathrm{~cm}$ flow). Helium gas (high purity) was used as a carrier gas. The temperature program for the analysis of 2-hydroxybiphenyl was $75^{\circ} \mathrm{C}(1 \mathrm{~min}$ isothermal $), 75^{\circ} \mathrm{C}$ to $200{ }^{\circ} \mathrm{C}\left(20{ }^{\circ} \mathrm{C} / \mathrm{min}\right), 200{ }^{\circ} \mathrm{C}$ to $280{ }^{\circ} \mathrm{C}\left(15^{\circ} \mathrm{C} / \mathrm{min}\right)$, and $280{ }^{\circ} \mathrm{C}$ (6.42 $\mathrm{min}$ isothermal). 


\section{Results and Discussion}

\subsection{Isolation of Bacteria}

To isolate bacteria harboring the capability of desulfurization petroleum from nature, soil samples with a history of oil pollution were chosen because most of the indigenous isolates living in these soils have acquired adaptable mechanisms. A total of forty soil samples were collected from different places in Iraq with a history of oil or its derivatives pollution.

To enrich the potential DBT desulfurizing bacterial isolates, BSM supplemented with $1 \mathrm{mM}$ of DBT as a sole source of sulfur with glycerol $(10 \mathrm{mM})$ as a carbon source, inoculated with a one percent (w/v) of soil samples. All the samples showed clear good growth after four days of incubation at 30 ${ }^{\circ} \mathrm{C}$. After that, these cultures were plated on LB to get on pure isolates. Sixty three bacterial isolates were obtained and these isolates were repeatedly tested in BSM supplemented with DBT, in order to ensure their utilizing ability (unpublished data).

\subsection{Screening of DBT Desulfurizing Bacteria}

All the sixty three isolates were subjected to Gibb's assay after four days of incubation. The results showed that three isolates (M9, M19 and S25) have the ability to desulfurize DBT and converted it to 2-HBP or other phenolic end products and gave blue color in the presence of Gibb's reagent. These isolates were repeatedly tested in BSM supplemented with DBT, in order to ensure their desulfurization ability (figure 1).

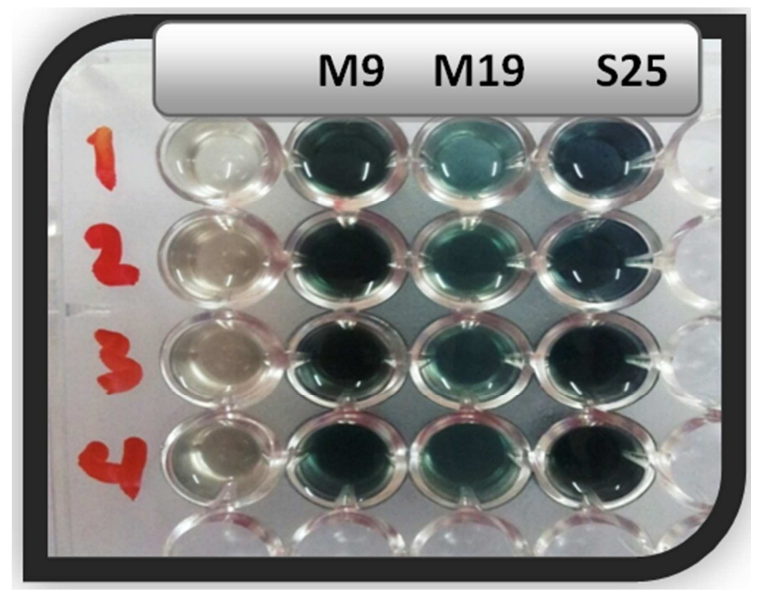

Figure 1. Gibb's assay guided desulfurization. The formation of blue color is an indication of desulfurization and formation of phenolic end products.

The results refereed that these isolates have the metabolic capability of $\mathrm{C}-\mathrm{S}$ bond cleavage and lacks the metabolic capability of attacking the carbon skeleton of DBT via the C-C bond cleavage. This preliminary result suggests the involvement of the $4 \mathrm{~S}$ pathway in the utilization of DBT via a specific cleavage of only the C-S bond by bacterial cultures exhibiting positive results with Gibb's reagent (Gupta et al., 2005; Mohebali and Ball, 2008).

\subsection{Identification of DBT Desulfurizing Bacteria}

The three isolates were identified according to morphological, cultural and biochemical characteristics. The results showed that these isolates belong to Pseudomonas aeruginosa. The morphological and biochemical characteristics for these isolates were in agreement with Holt et al. (1994). Moreover, identification of the bacterial isolates was confirmed by using the VITEK 2 system. The results of the tests used in this system confirmed the results obtained from morphological and biochemical tests.

\subsection{Selection the Efficient Isolate That Capable of Desulfurizing DBT}

To select one isolate from the three $P$. aeruginosa isolates (M9, M19 and S25) based on the efficiency of removing sulfur atom from DBT, Gibb's assay was performed. The concentration of the end product (2-HBP or other phenolic end products), resulted from $4 \mathrm{~S}$ pathway in culture grown with DBT was quantified by measuring the intensity of the corresponding blue color formed after addition of Gibb's reagent (Akbar, 2008). The obtained results (table 1) showed increased the concentration (intensity) of the 2-HBP with increase the concentration of DBT, after bacterial growth at 35 ${ }^{\circ} \mathrm{C}$ (optimum temperature, unpublished data) for 4 days.

Table 1. Detection of 2-HBP using Gibb's reagent in culture supernatants of bacteria growing with double concentrations of DBT in BSM medium at $35^{\circ} \mathrm{C}$ for 4 days.

\begin{tabular}{llllll}
\hline \multirow{2}{*}{ Isolates } & \multicolumn{6}{l}{ Concentration of DBT } & & \\
\cline { 2 - 6 } & $\mathbf{0 . 1} \mathbf{~ m M}$ & $\mathbf{0 . 2} \mathbf{~ m M}$ & $\mathbf{0 . 4} \mathbf{~ m M}$ & $\mathbf{0 . 8} \mathbf{~ m M}$ & \\
\hline$P$. aeruginosa-M9 & 0.013 & 0.079 & 0.145 & 0.175 & \\
$P$. aeruginosa-M19 & 0.020 & 0.039 & 0.109 & 0.145 & \multirow{2}{*}{ O.D $_{610}$} \\
$P$. aeruginosa-S25 & 0.082 & 0.115 & 0.185 & 0.294 & \\
\hline
\end{tabular}

$P$. aeruginosa $\mathrm{S} 25$ gave obvious blue color upon addition of Gibb's reagent compared to other isolates. This indicated that $P$. aeruginosa $\mathrm{S} 25$ isolate is the most efficient one for utilizing sulfur in DBT, that was clear by a higher concentration (intensity) of the phenolic compounds accumulation.

\subsection{Detection and Verifying the Biodesulfurizing End Products by GC/MS Analysis}

The GC/MS analysis for the control (DBT-BSM) showed only one peak (figure 2), which represented DBT. Analysis of bacterial culture on DBT-BSM indicated that, as much as $12.89 \%$ of DBT consumed (which represent consumption of sulfur) by the $P$. aeruginosa-S25 (which gave 32 peaks) (figure 3), depending on the area of the peaks (there is a direct proportion between the area of the peak and the concentration).

$P$. aeruginosa-S25 showed good ability to consume sulfur when compared with other bacterial isolates in literature. Al-Hassar (2010) isolated two bacterial isolates assigned as 233 and 343 , that have the ability to desulfurize $8 \%$ and $4 \%$ of sulfur respectively.

The peak area appeared at a retention time of 9.867 for the control sample (DBT-BSM) was 8,942,827 (figure 2), this 
area was reduced to $1,153,056$ and appeared at retention time of 9.817 (figure 3 and 4). The analysis of the DBT control sample gave only one peak, and this mean that DBT was pure and probably its purity was $91 \%$ (SI: 91) with molecular weight 184 (figure 5).

Results (figure 6) showed also that there was further converted of 2-HBP to 1, 2-Naphthalenediol, 2-ethyl-1, 2, 3, 4-tetrahydro-, cis and to 4-Methoxybenzhydrol at retention time $(9.150,12.367)$ respectively. This is like the conversion of 2HBP to 4-MBP by methylation at the hydroxyl group (Rhee et al., 1998). Therefore, it could be a novel pathway of DBT utilization by $P$. aeruginosa-S25, similar to the $4 \mathrm{~S}$ pathway except that 2-HBP was further converted to 2-MBP (by addition methyl group).

In biodesulfurization, DBT is converted to $2-\mathrm{HBP}$, which will increase the possibility of environmental pollution (Ichinose et al., 1999). In contrast, methylation of the hydroxyl group of 2-HBP by bacteria may partially eliminate the inhibitory effect of the product and the pollution from diesel oil combustion (Monticello et al., 2000). Therefore, it was suggested that the pathway followed by $P$. aeruginosa-S25 is the sulfur-selective pathway for utilization of DBT as reported earlier by Oldfield et al. (1997).

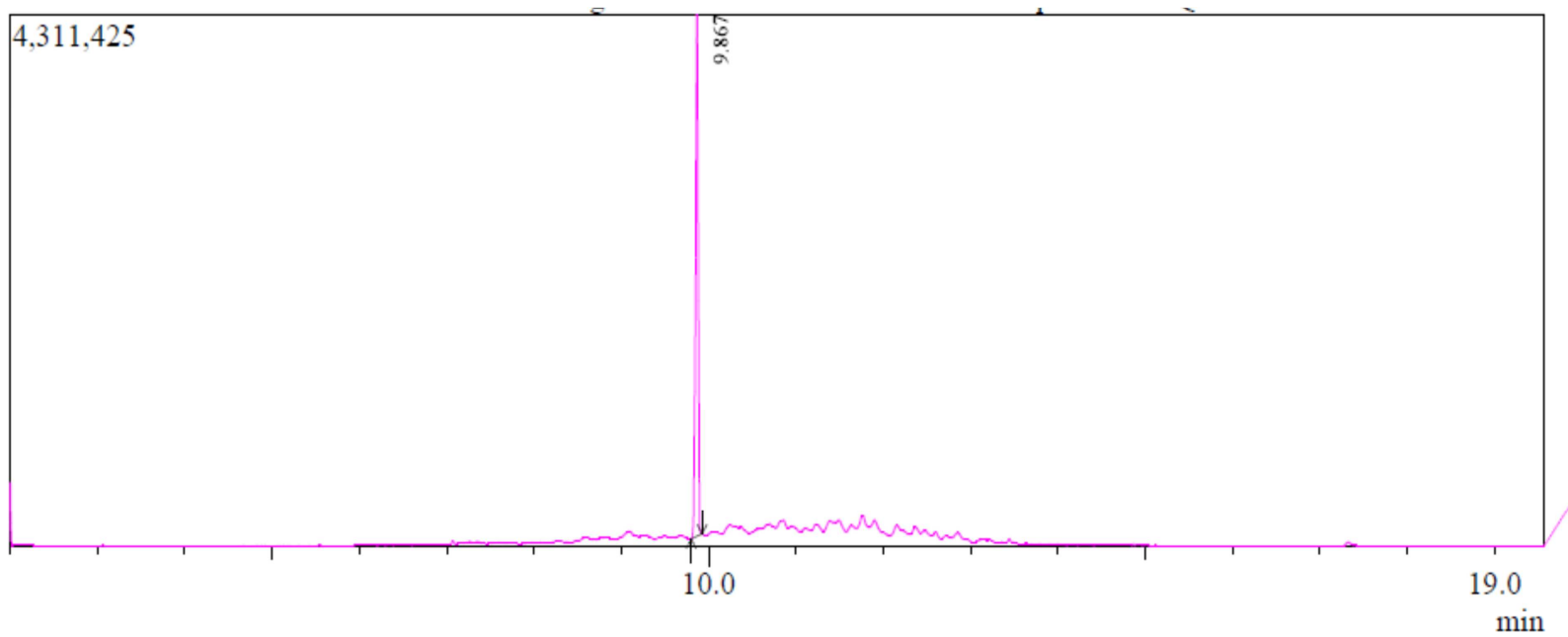

\begin{tabular}{|c|c|c|c|c|c|c|c|c|c|c|}
\hline & & \multicolumn{9}{|c|}{ Peak Report TIC } \\
\hline Peak\# & R. Time & I. Time & F.Time & Area & Area $\%$ & Height & Height $\%$ & $\mathrm{~A} / \mathrm{H}$ & Mark & Name \\
\hline 1 & 9.867 & 9.800 & 9.925 & 8942827 & 100.00 & 4223480 & 100.00 & 2.12 & MI & \\
\hline & & & & 8942827 & 100.00 & 4223480 & 100.00 & & & \\
\hline
\end{tabular}

Figure 2. GC/MS chromatogram of control sample (DBT-BSM lacking bacterial cell). That gives one peak at retention time 9.86 which represent DBT peak.

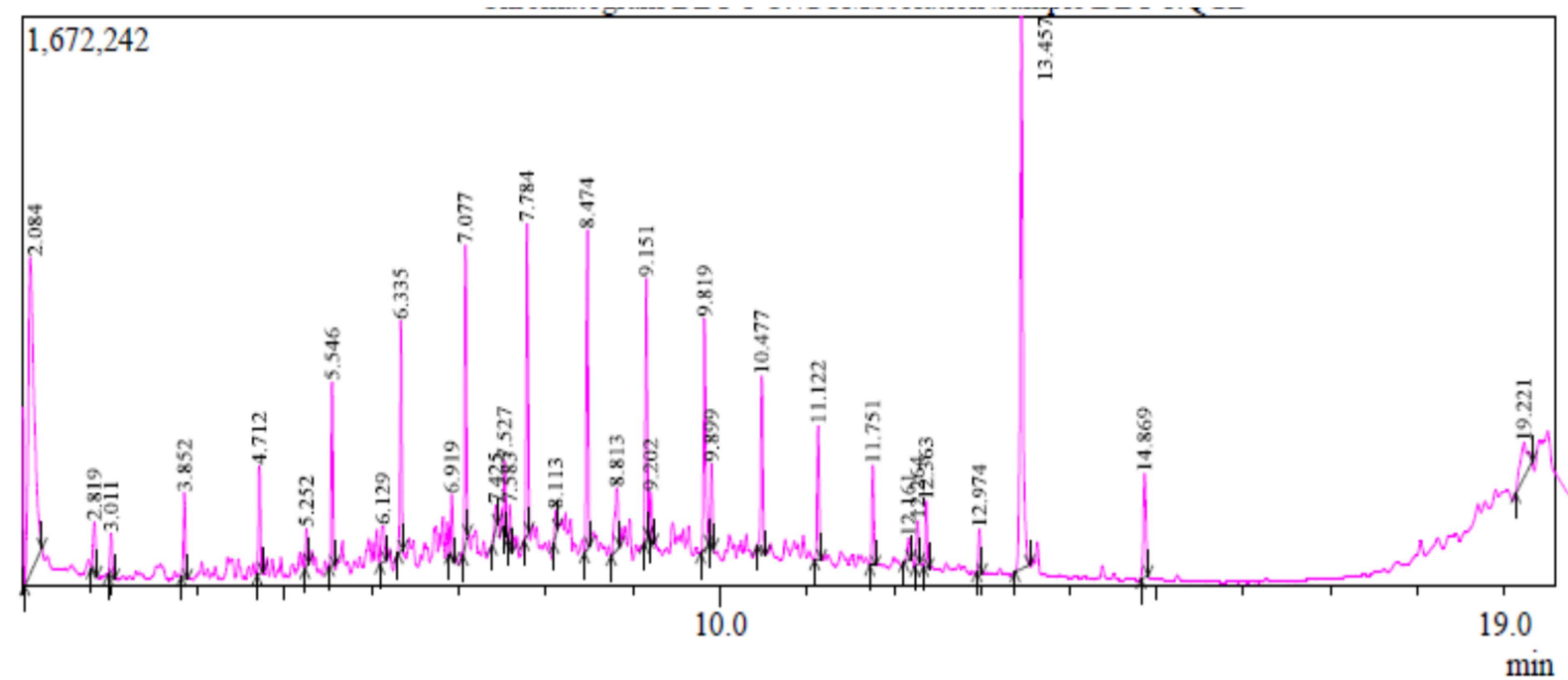

$\mathrm{TIC}^{*} 1.00$

Figure 3. GC/MS chromatogram of P. aeruginosa-S25 DBT-BSM supernatant extracted culture. That gives 32 peaks with DBT peak (21) at retention time 9.81. 
Line: 20 R.Time:9.817(Scan\#:939) MassPeaks:27

RawMode:Averaged 9.783-9.867(935-945) BasePeak:184.05(7765)

BGMode:9.808(938) Group 1 - Event 1

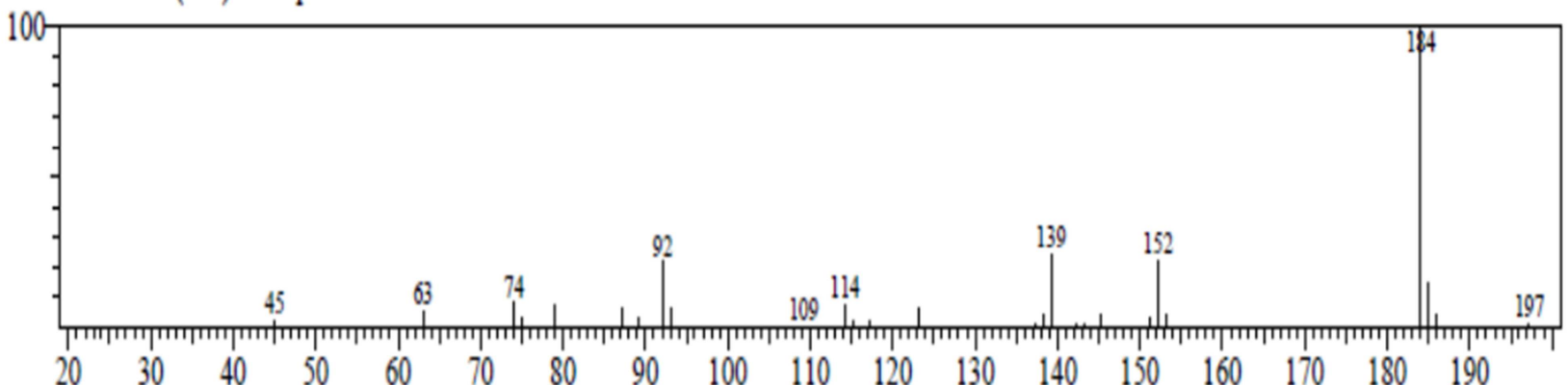

SI:82 Formula:C12H8S CAS:132-65-0 MolWeight:184 RetIndex:1635

CompName:Dibenzothiophene \$ [1,1'-Biphenyl]-2,2'-diyl sulfide \$\$ Dibenzo[b,d] thiophene \$\$ Diphenylene sulfide \$\$ 2,2'-Biphenylylene sulfide \$\$ 9

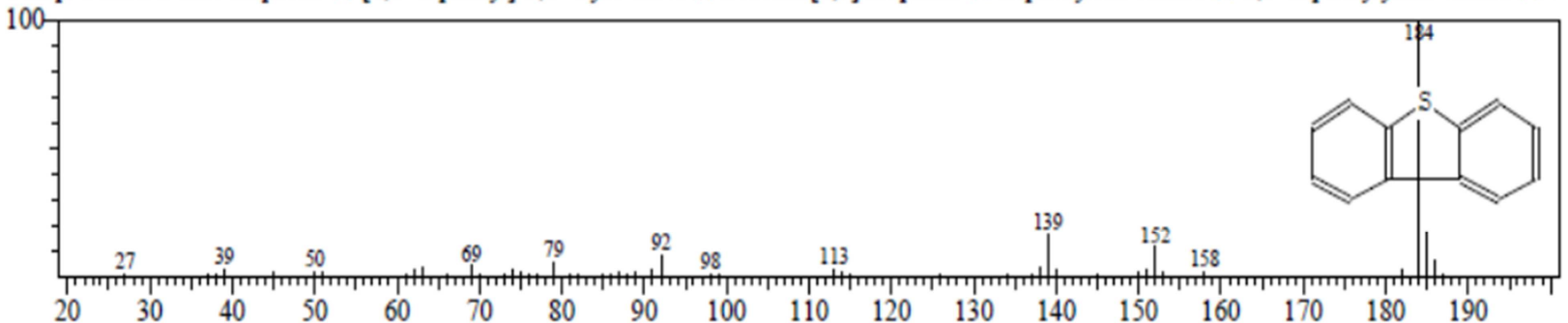

Figure 4. GC/MS analysis showing the mass spectrum of DBT (molecular mass, 184) with specific identity 82.

\section{Linef:1 RTime:9.867(Scant:945) MassPeaks:108}

Raw:Mode:Averaged 9.800-9.925(937-952) BasePeak:184.05(371191)

BGMode:9.950(955) Group 1 - Event 1

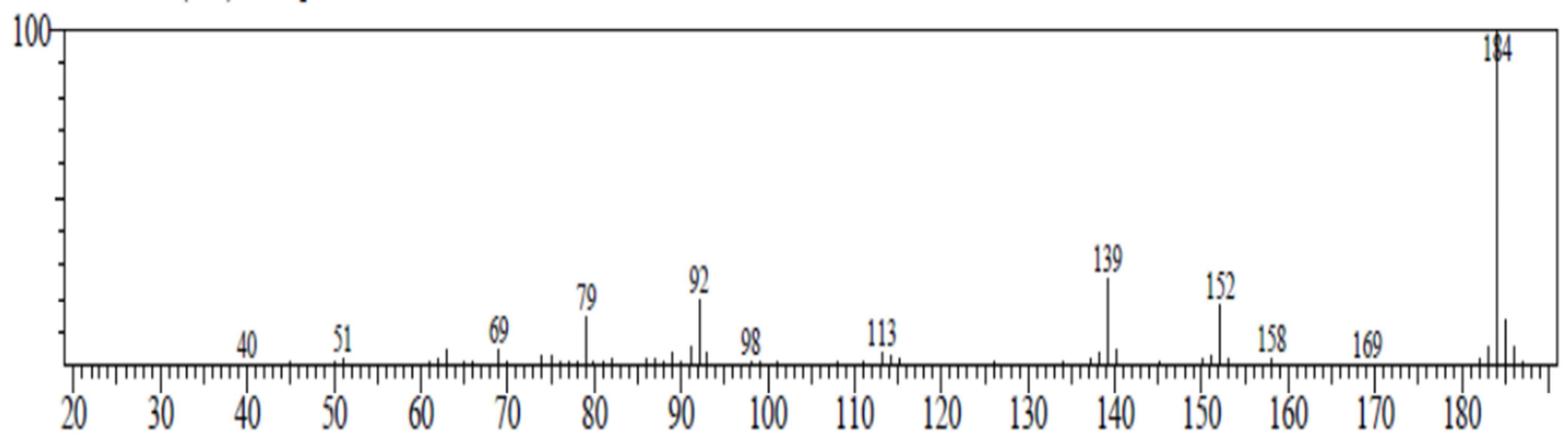

SI:91 Formula:C12H8S CAS:132-65-0 MolWeight:184 RetIndex:1635

CompName:Dibenzothiophene \$\$ [1,1'-Biphenyl]-2,2'-diyl sulfide \$ Dibenzo[b,d]thiophene \$\$ Diphenylene sulfide \$\$ 2,2'-Biphenylylene sulfide \$\$ S

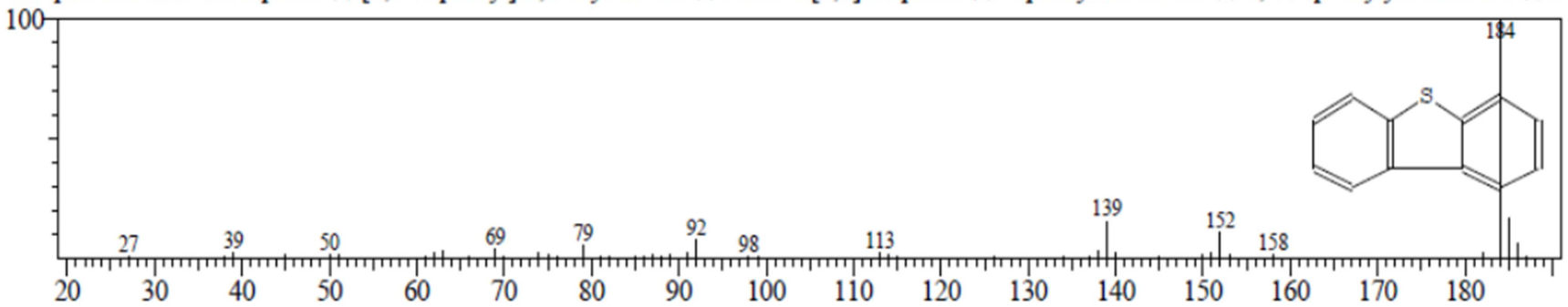

Figure 5. GC/MS analysis showing the mass spectrum of DBT (molecular mass, 184) with specific identity 91. 
Line=-18 R Time-9.150(Scan=-859) MassPeaks:14

RawMode:Areraged 9.125-9.175(856-862) BasePeak-120.20(638)

BGMode-9.142(858) Group 1 - Event 1

100

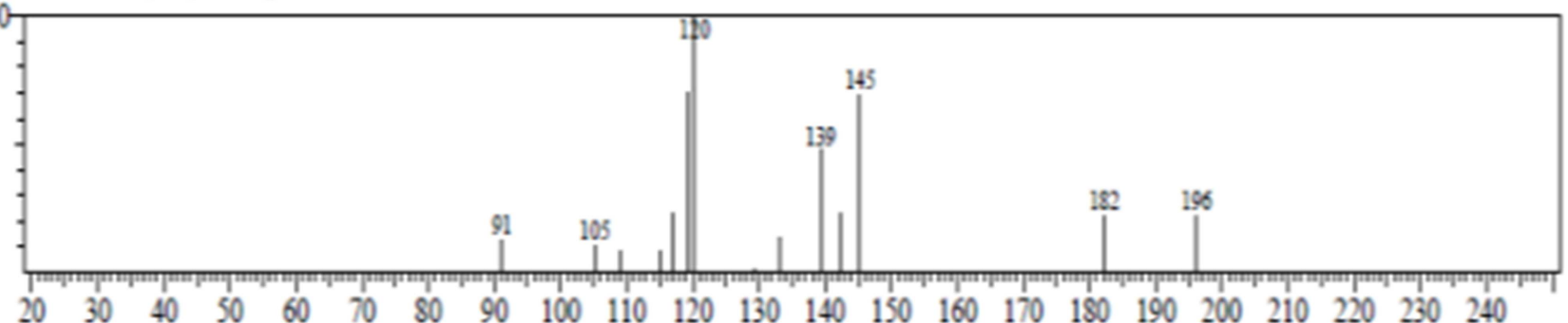

SI.63 Formula:C12H1602 CAS:5658s-39-7 MorWeight:192 Retindex:1665

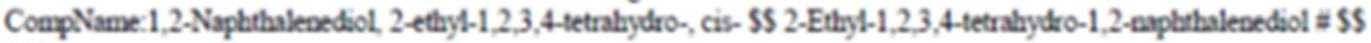

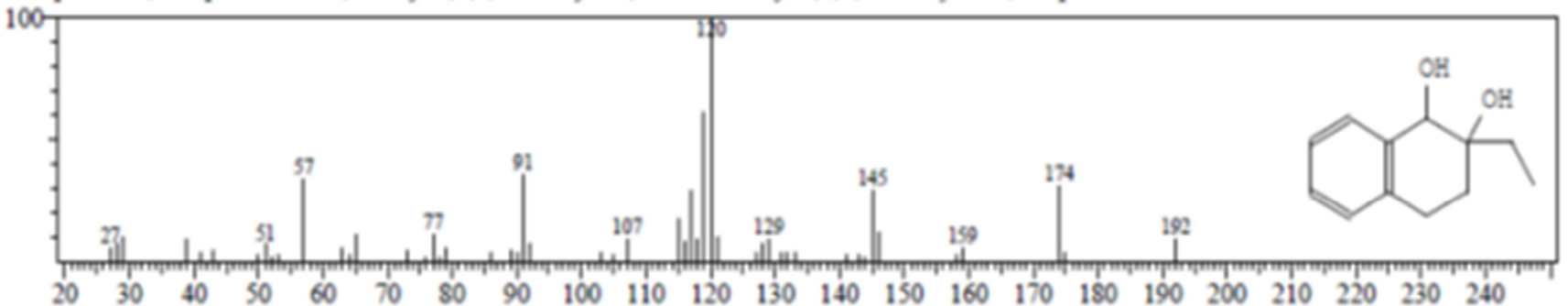

SI-64 Formula:C14H1402 CAS:720-44-5 MolWeight214 Retindex1818

CompName:4-Methoxybenzhydrol SS Benzenemethanol, 4-methoxy-alpha -pbenyl-SS (4-Methox

P. aeruginosa-S25 DBT-BSM

100

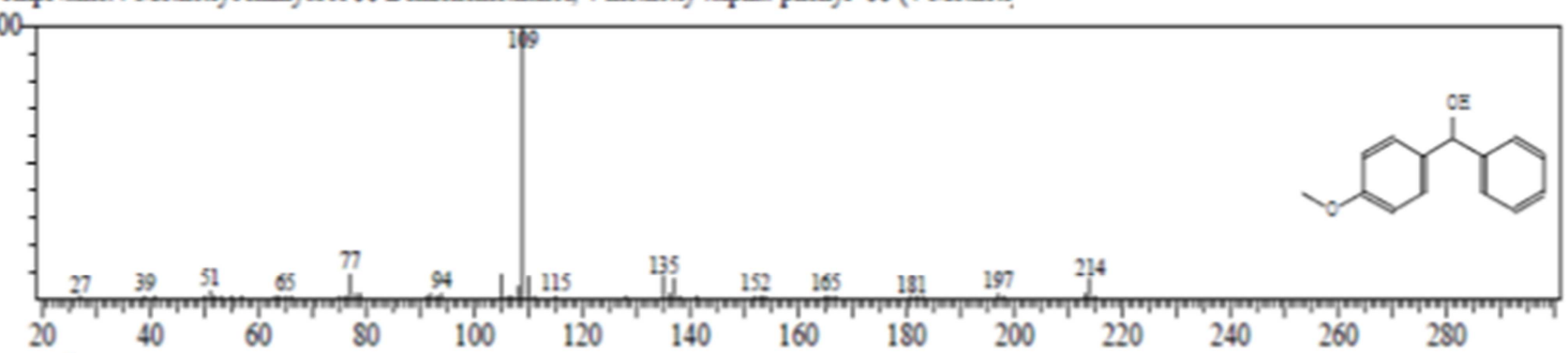

Line: 27 RTme:12.367(Scan=1245) MassPeaks:4

Ran:Mode:Averaged 12.325-12.392(1240-1248) BasePeak-109.15(335)

BG Mode:12358(1244) Growp 1 - Eveat 1

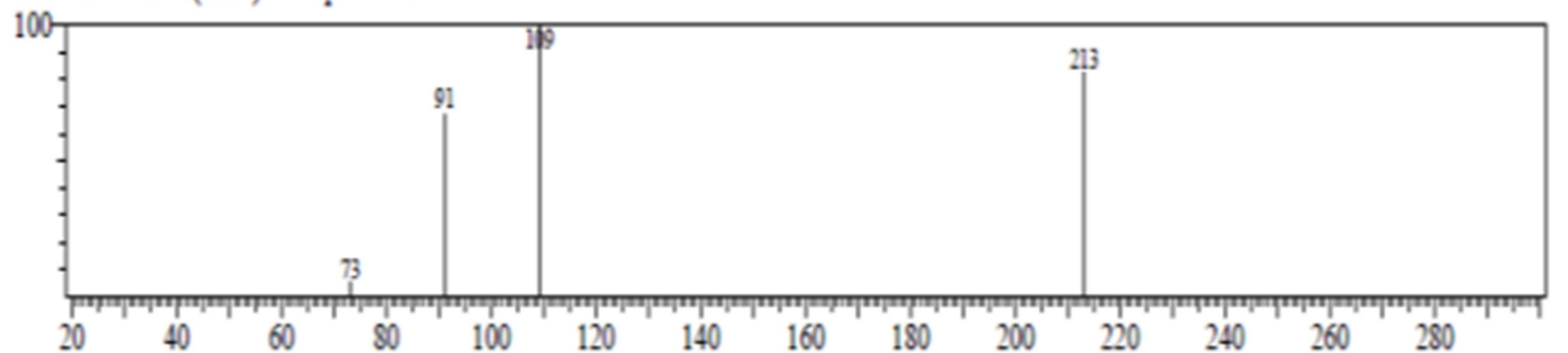

Figure 6. GC/MS analysis showing the mass spectrum of 1, 2 Naphthalenediol, 2- ethyl-1, 2, 3, 4-tetrahydro-, cis (molecular mass, 192) with retention time 9.15 and the mass spectrum of 4-Methoxybenzhydrol (molecular mass, 214) with retention time 12.36.

\section{Conclusion}

The pathway followed by $P$. aeruginosa-S25 is the sulfur-selective pathway for utilization of DBT, it could be a novel pathway. The 2-HBP (product) was further converted to 2-MBP (by addition, methyl group), this may eliminate the inhibitory effect of 2-HBP and the pollution from crude oil and diesel oil combustion. This is promising feature that makes $P$. aeruginosa-S25 potential candidate for developing a biocatalytic desulfurization process for fuels. 


\section{Acknowledgments}

The authors would like to acknowledge the support provided by the Deanship of College of Science and College of Biotechnology at Al-Nahrain University.

\section{References}

[1] Akbar, A. H., 2008. Characterization of Some Benzothiophene and Dibenzothiophene Utilizing Bacteria. M. sc. Thesis. College of graduate studies- Arabian Gulf University.

[2] Al-Hassar, Z. A., 2010. Biodegradation and Biodesulfuruzation Substrate Spectrum for Dibenzothiophene-Desulfurizing Bacteria. M. sc. Thesis. College of graduate studies- Arabian Gulf University.

[3] Alves, L., Paixão, S. M., 2011. Toxicity Evaluation of 2-Hydroxybiphenyl and Other Compounds Involved in Studies of Fossil Fuels Biodesulphurisation. J. Bioresour. Technol., 102: 9162-9166.

[4] Chen, H., Cai, YB., Zhang, W. J., Li, W., 2009. Methoxylation pathway in biodesulfurization of model organosulfur compounds with Mycobacterium sp. J. Bioresour. Technol.; 100: 2085-2087.

[5] Gao, L. D., Tang, Y., Xue, Q. S., Liu, Y., Lu, Y., 2009. Hydrotalcite-like compounds derived $\mathrm{Cu} \mathrm{Zn}$ Al oxide catalysts for aerobic oxidative removal of gasoline-range organosulfur compounds. Energy Fuels. 23, 624-630.

[6] Gupta, N., Roychoudhury, P. K., Deb, J. K., 2005. Biotechnology of desulfurization of diesel: Prospects and challenges. Appl. Microbiol. Biotechnol. 66: 356-366.

[7] Holt, J. G., Krieg, N. R., Sneath, H. A., Staley, J. T., Williams, S T., 1994. Bergys manual of determinative bacteriology. 9th ed. Williams and Wilkins, USA.

[8] Ichinose, H., Wariishi, H., Tanaka, H., 1999. Bioconversion of recalcitrant 4-methyldibenzothiophene to water-extractable products using lignin-degrading basidiomycete Coriolus versicolor. Biotechnol. Prog. 15: 706-714.

[9] Kilbane, J. J., 2006. Microbial biocatalyst development to upgrade fossil fuels. Curr Opin Biotechnol 17, 305-314.

[10] Konishi, J., Ishii, Y., Onaka, T., Okumura, K., Suzuki, M., 1997. Thermophilicarbon-sulfur-bond-targeted biode-sulfurization. Appl. Environ. Microbiol. 63 (8): 3164-9.
[11] Liu, H., Yu, J., Bao, X., 2007. The State-of-the-art and future perspectives of world petroleum refining technology [J]. The Chinese Journal of Process Engineering. 7 (1): 176 -185.

[12] Ma, C., Dai, B., Xu, C., Liu, P., Qi, L., Ban, L., 2013. Deep oxidative desulfurization of model fuel via dielectric barrier discharge plasma oxidation using $\mathrm{MnO} 2$ catalysts and combination of ionic liquid extraction. Catal. Today. 211, 84-89.

[13] Mandal, A. J., Sarma, P. M., Singh, B., Jeyaseelan, C. P., Channashettar, V. A., 2012. Bioremediation: An environment friendly, sustainable biotechnological solution for remediation of petroleum hydrocarbon contaminated waste. ARPN Journal of Science and Technology 2 (Special Issue): 1-12.

[14] Mohebali, G., Ball, A. S., 2008. Biocatalytic desulfurization (BDS) of petrodiesel fuels. Microbiology 154:2169-2183.

[15] Mohebali, G., Ball, A., Rasekh, B., Kaytash, A., 2007. Biodesulfurization potential of a newly isolated bacterium, Gordonia alkanivorans RIPI190A. Enzyme and Microbial Technol., 40: 578-584.

[16] Monticello, D. J., 2000. Biodesulfurization and the upgrading of petroleum distillates. Current Opinion in Biotechnology, 11, 540-546.

[17] Oldfield, C., Pogrebinsky, O., Simmonds, J., Olson, E. S., Kulpa, C., 1997. Elucidation of the metabolic pathway for dibenzothiophene desulphurization by Rhodococcus sp. strain IGTS8 (ATCC 53968). Microbiology 143: 2961-2973.

[18] Rambosek, J., Piddington, C. S., Kovacevich, B. R., Young, K. D., Denome S. A., 1994. Recombinant DNA encoding a desulfurization biocatalyst. U.S. Patent 5356801.

[19] Rhee, S. K., Chang, J. H., Chang, Y. K., Chang, H. N., 1998. Desulfurization of Dibenzothiophene and Diesel Oil by Newly Isolated Gordona strain, CYKS1. Applied and Environmental Micobiol., 64 : 2327-2331.

[20] Smart, K. F., Aggio, R. B. M., Van Houtte, J. R., Villas-Boas, S. G., 2010. Analytical platform for metabolome analysis of microbial cells using methyl chloroformate derivatization followed by gas chromatography-mass spectrometry. Nat. Protoc. 5, 1709-1729.

[21] Xu, P., Feng, J., Yu, B., Li, F., Ma, C., 2009. Recent developments in biodesulfurization of fossil fuels. Adv Biochem Eng Biotechnol 113:255-274. 